\title{
DA PAIXÃO PELA ETNOLOGIA à ETNOLOGIA DAS PAIXÕES CONIEMPORÂNEAS
}

\section{Arlei Sander Damo}

Universidade Federal do Rio Grande do Sul - Brasil

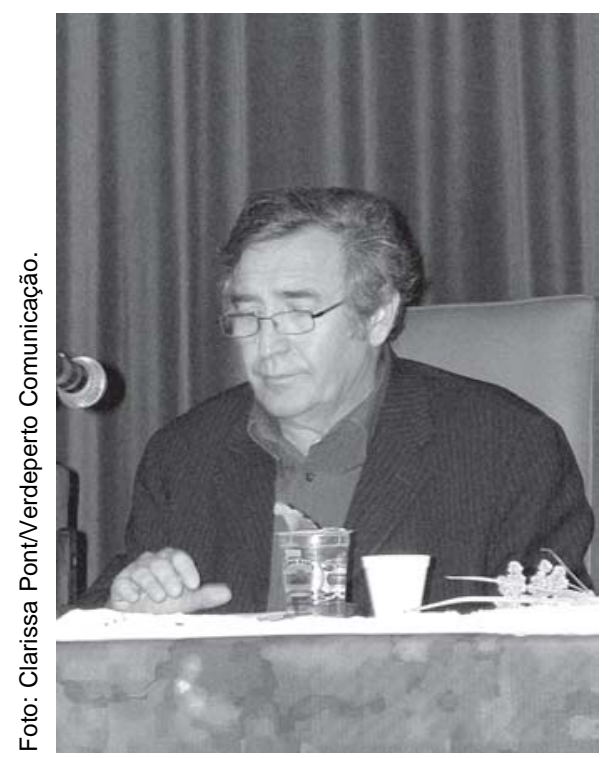

Christian Bromberger em Porto Alegre, durante a VII RAM, em julho de 2007.
Christian Bromberger é um dos antropólogos franceses mais respeitados na atualidade. Embora mais conhecido como especialista em Irã, sua obra é vasta e diversificada, perpassando temas como o patrimônio material, as culturas mediterrâneas, a pilosidade (tratamento dos pelos e cabelos) e o esporte, evidentemente. Ele próprio se reivindica um etnólogo itinerante, e as razões destas reivindicações o leitor encontrará no texto aqui traduzido. ${ }^{1}$

Aluno de Roger Bastide e André Leroi-Gourhan, por quem foi orientado, Bromberger escolheu a província iraniana do Gilân, localizada junto ao mar Cáspio, como uma espécie de refúgio etnográfico, o local para o qual retorna depois de incursões por outros lugares.

Diferentemente do Brasil e de outros contextos nos quais o termo antropólogo tem uso alargado e irrestrito, na França ainda persistem certas fronteiras entre a etnologia e a antropologia, este último é um qualificativo supostamente mais pomposo, restrito aos grandes mestres versados em temas universais. 
Desde a primeira estada no Gilân, no final da década de 1980, Bromberger tem freqüentado regularmente o Irã, à exceção de um período, em meados da mesma década, quando a vigilância do regime islâmico recrudesceu a ponto de inviabilizar o trabalho de campo. O contato prolongado com os habitantes do Gilân tem lhe permitido acompanhar de perto a dinâmica da sociedade iraniana, algo muito mais complexo do que a visão estereotipada difundida pela mídia ocidental. Um breve esboço desta complexidade, matizada por uma etnografia arrojada, nos foi apresentada pelo próprio Bromberger em sua conferência na VII Reunião de Antropologia do Mercosul, realizada em Porto Alegre, em julho de 2007.

Mas o que teria levado um etnólogo consolidado, com larga experiência em trabalho de campo nos cânones sugeridos pela disciplina, a se interessar pelo futebol? De que forma a experiência acumulada no Gilân - ou mesmo no interior da região da Provença, onde Bromberger desenvolveu diversas pesquisas - influenciou a etnografia nos estádios e nas ruas das grandes metrópoles européias? Qual o nexo entre tudo isso, afinal?

Segundo Bromberger, "foi vendo pescadores turcos azeris [de confissão mulçumana xiita] jogar futebol nas praias do mar Cáspio que a idéia de trabalhar sobre o futebol na Europa ganhou corpo" (Cunha; Durand, 2004, p. 364). Todavia, o despertar inusitado não teria ocorrido não houvesse ele, há mais tempo, se interessado "por esses momentos em que uma sociedade mexe, ri, chora e grita"; em tais momentos, prossegue Bromberger, "tenho a sensação de que se exprimem, num modo teatral, os valores fundamentais que orientam uma sociedade. E esta atenção às formas sensíveis e efervescentes da vida social é sem dúvida uma das constantes do meu percurso” (Cunha; Durand, 2004, p. 363).

O interesse por questões atinentes às sensibilidades cotidianas não descarta a dimensão política da vida social. Mesmo quando se perscrutam as emoções, afirma Bromberger, o foco do etnólogo será sempre a dimensão simbólica das experiências sensíveis, ou por outra, o arcabouço social e cultural que suscita o riso e choro, a euforia e a decepção, o êxtase e a dor, e assim por diante. Daí por que as paixões coletivas, e é neste rol que Bromberger encaixa o futebol, sejam excelentes postos de observação, lugares a partir dos quais se pode compreender a especificidade de um grupo combinando os pontos de vista ético e êmico.

É através daquilo que os nativos consideram fútil, irrisório e banal que, por vezes, pode-se chegar mais facilmente às coisas que interessam efetivamente, 
como fez Geertz ao interpretar a briga de galos balinesa. Não é à toa, pois, que Bromberger trata o futebol como "a bagaleta mais séria do mundo" - tendo, inclusive, nomeado um de seus livros como este sugestivo subtítulo (Bromberger, 2004) - e se dedicado à publicação de uma coletânea chamada de Passions Ordinaires (Bromberger, 1998), na qual reúne artigos sobre temas tão diversos como: concurso de ditado, animais de companhia, coleção de selos, ciclismo, futebol, entre outros.

É pelo livro Le Match de Football: Ethnologie d'une Passion Partisane à Marseille, Naples et Turin, lançado em 1995, que Bromberger tornou-se referência para quem trabalha no assunto, embora a obra tenha méritos que ultrapassam os interesses de um grupo de especialistas em futebol. Le Match de Football revela, entre outras qualidades, o talento de Bromberger para a escrita, algo por vezes raro de ser encontrado em textos científicos. Trata-se de um texto etnográfico que conduz o leitor aos lugares nos quais as tramas de campo aconteceram, porque nele o autor imprime o ponto de vista dos sujeitos com os quais esteve em tempos e espaços bem definidos. É uma etnografia de fôlego, realizada em três cidades distintas, como esclarece o subtítulo, em espaços polifônicos por excelência e, por isso mesmo, tão desafiadores como são os estádios de futebol. Ao combinar procedimentos clássicos da sociologia como os surveys usados para definir o perfil de diferentes agrupamentos de torcedores no interior dos estádios - com as técnicas da observação participante, Bromberger produziu uma etnografia de vanguarda, na perspectiva multisited defendida por George Marcus.

Com tantas credenciais, é quase incompreensível que só agora Bromberger esteja sendo mais bem divulgado aos leitores de língua portuguesa. Isto se explica, em parte, pelo fato de que nossas trocas com antropólogos da região mediterrânea são efêmeras, e vice-versa. Bromberger foi um dos idealizadores e por diversas vezes diretor do Institut d'Ethnologie Méditerranéenne et Comparative (Idemec). ${ }^{2}$ Fundado em 1983 e atualmente um dos mais dinâmicos centros de ensino e pesquisa em antropologia da França, o Idemec destaca-se, sobretudo, pelo fluxo intenso de pesquisadores africanos, especialmente do Magreb. Tendo publicações em parceria com Marc Áuge, Tzvetan Todorov

2 O Idemec é uma Unité Mixte de Recherche, associada ao CNRS e vinculada à Universidade de AixMarseille I e III, estando situada na cidade de Aix-en-Provence.

Horizontes Antropológicos, Porto Alegre, ano 14, n. 30, p. 233-236, jul./dez. 2008 
e Martine Segalen, apenas para citar nomes bem conhecidos no Brasil, era já tempo de tornar Bromberger mais acessível aos leitores da língua portuguesa. Para os interessados na "bagatela" futebolística, bem como nos esportes em geral, Bromberger é referência obrigatória, e o texto aqui publicado - ainda inédito - poderá ser um convite às dezenas de publicações do autor sobre este tema. $^{3}$

\section{Referências}

BROMBERGER, C. Le match de football: ethnologie d'une passion partisane à Marseille, Naples et Turin. Paris: Maison des Sciences de l'Homme, 1995.

BROMBERGER, C. (Org.). Passions ordinaires: du match de football au concours de dictée. Paris: Bayard, 1998.

BROMBERGER, C. Football: la bagatelle la plus sérieuse du monde. Paris: Pocket, 2004.

CUNHA, M. I.; DURAND, J.-Y. “Como é que isto funciona..." - entrevista com Christian Bromberger. Etnográfica, v. 8, n. 2, p. 357-376, 2004.

${ }^{3}$ Uma lista completa das publicações de Bromberger pode ser encontrada em: http://www.mmsh.univaix.fr/idemec/Membres/Membres-publications/BROMBERGER.htm. 